\title{
THE PROFESSIONAL NURSE'S EXPERIENCE OF THE DYING PROCESS OF THE TERMINAL AIDS PATIENT
}

\section{Mrs Petra Bester}

M Cur (Psychiatric Community Nursing Science)

School of Nursing Science, North-West University, Potchefstroom Campus

\section{Mrs Engela du Plessis}

MA (Professional Nursing Science)

Senior Lecturer, School of Nursing Science, North-West University, Potchefstroom Campus

Corresponding author:vpkedp@puk.ac.za

\author{
Prof Minrie Greeff \\ D Cur (Psychiatric Nursing) \\ Professor, School of Nursing Science, North-West University, Potchefstroom Campus
}

Keywords: nurse; experience; dying process; Human Immunodeficiency Virus (HIV); HIV-positive patient; Acquired Immunodeficiency Syndrome (AIDS); terminal AIDS patient; facilitate

\section{OPSOMMING}

Die toename in MIVIVIGS wek internasionale kommer. Statistiek toon dat Suid-Afrika die snelstygendste MIVbesmettingskoers ter wêreld het. Hierdie toename word gekompliseer deur sekondêre infeksies wat lei tot 'n toename in hospitalisasie en dood van terminale VIGS-pasiënte. Die verpleegkundige word toenemend hieraan blootgestel. Dit het die navorsers daartoe gelei om deur ' $n$ kwalitatiewe navorsingsontwerp die verpleegkundige se belewenis van die sterwensproses van die terminale VIGS-pasiënt te verken en te beskryf. ' $n$ Doelgerigte, vrywillige steekproef is uitgevoer en individuele onderhoude is gevoer totdat dataversadiging na 10 onderhoude bereik is. Data-analise is uitgevoer en 'n medekodeerder is betrek om vertrouenswaardigheid te versterk. Die resultate het in die volgende tema's gekristalliseer: eerstens beleef die verpleegkundige dat verskillende aspekte die verloop van die sterwensproses beïnvloed; tweedens het kontrasterende belewenisse ten opsigte van die mediese behandeling na vore getree; derdens het spesifieke behoeftes en gedrag van die terminale VIGS-pasiënt en spesifeke gedrag van die verpleegkundige gemanifesteer. Die verpleegkundige het ook emosies soos magteloosheid, verligting en vrees beleef. Waarde-oordele ten opsigte van die pasiënt, sy familie, mediese behandeling en die verpleegkundige se optrede is ook gemerk. Aanbevelings sluit in: verpleegkundiges se persoonlike hantering van die sterwensproses, uitgebreide hanteringsvaardighede in die sterwensbegeleiding van terminale VIGS-pasiënte en hulle hantering van spesifieke temas gedurende die sterwensproses.

\section{ABSTRACT}

The increase in HIVIAIDS raises international concern. Statistics indicate that South Africa has the fastest increasing HIV-infection rate in the world. Secondary infections complicate the issues and could result in hospitalisation and death of terminal AIDS patients. Nurses are increasingly exposed to this process. This directed the researchers to explore and describe the nurse's experience of the dying process of the terminal AIDS patient through a qualitative research design. Purposive, voluntary sampling was conducted followed by individual interviews. Data saturation was reached after 10 interviews. The data were then analysed involving a co-coder to ensure trustworthiness. The results indicated specific themes. Firstly, nurses experience that various factors influence the pace of the dying process. Secondly, contrasting experiences regarding medical treatment of these patients surfaced. The study indicated that the nurse experienced emotions such as powerlessness, relief and fear. Finally, the needs and behaviours of the terminal AIDS patient, and the specific behaviours of the nurses were revealed. Value judgements 
regarding the patient, his family, medical treatment and the nurse's conduct during the dying process were also noted. Recommendations focus on the following: nurses' personal coping with the dying process, extended coping skills in the guidance of terminal AIDS patients and their handling of specific themes during the dying process.

\section{INTRODUCTION AND PROBLEM STATE- MENT}

HIV and AIDS are a gross reality in Africa as the World Health Organization (WHO) (2000:3) indicates that up to $70 \%$ of the 42 million HIV-infected people live in Africa. This pandemic raises particular concern in SubSaharan Africa, where an estimated 26.6 million people are either HIV positive or have AIDS (Anon, 2005a; slide 4 ; WHO, 2000). South Africa also displays a bleak picture when the South African Department of Health (2003:6) found that $26.5 \%$ of the population (of 44.8 million) is HIV positive. Amongst the South African provinces, KwaZulu-Natal has the highest prevalence of HIV and AIDS (36.5\%). In the North West Province, where this research was conducted, an estimated $26.2 \%$ of the population has HIV and AIDS.

The North West Province is a mostly rural province where hospitals are congested with HIV and AIDS patients (Anon, 1998a:6, Sunter in Anon, 1998b:9-10). These patients are hospitalised, suffering from fatal opportunistic infections and secondary complications due to a depleted immune system (Saab \& Seoud, 1998:326). Several authors agree that the professional nurse is the health care practitioner most confronted by the dying process of the terminally ill AIDS patient (Bester \& Arendse, 1996:64, Chamane \& Kortenbout, 1997:43).

According to Torrente and Greeff (1996:11) nurses are personally influenced when they nurse the terminally ill in general. Prior studies stipulate that professional nurses generally experience intrapersonal discomfort and stress when nursing a terminally ill patient. It is argued that the dying process of the patient confronts them with their own mortality (Payne, Dean \& Kalus, 1998:700; Robbins \& Moscrop, 1995:174). According to St Leger (1995:5) and Swanepoel (1998:11) stress may be intensified when nursing a terminally ill AIDS patient, as AIDS inevitably causes death (Swanepoel, 1998:11). Furthermore, these patients die at a relatively young age (15-24 years) and may be discriminated against or rejected by family and friends (Chipfakacha, 1998:1-15).
Therefore, the dying process of the terminally ill AIDS patient becomes a particularly fearful and unnatural event (Illich in O'Gorman, 1998:1128) that may influence the professional nurse severely. Despite this, the nursing code of conduct obliges the professional nurse to give care to the terminal AIDS patient (Botes, 1994:69), which leads to an unavoidable confrontation with this dying process. In the researcher's subjective experience, professional nurses increasingly request guidance in this regard, although little or no support is available. The above triggered the following questions: "How does the professional nurse experience the dying process of the terminally ill AIDS patient?" and, "How might she/he cope more effectively when confronted with the dying process of the terminally ill AIDS patient?" These questions lead to the following research objectives: to explore and describe the nurse's experience of the dying process of the terminally ill AIDS patient, and to formulate guidelines to facilitate the professional nurse to cope more effectively with this inevitable confrontation with the dying process of the terminally ill AIDS patient.

\section{PARADIGMATIC PERSPECTIVE}

Meta-theoretical, theoretical and methodological assumptions from the paradigmatic perspective of this research. Meta-theoretical assumptions constitute Herman Dooyeweerd's Christian worldviews (in Botha, 1995:1-209), combined with the Nursing Theory for the Whole Person (Oral Roberts University Anna Vaughn School for Nursing, 1989:136-143). These assumptions directed the description of the following core concepts: man, health, environment and nursing. Theoretical assumptions include the central theoretical statement, and conceptual descriptions of professional nurse, experience, dying process, HIV, HIV positive patient, AIDS and terminally ill AIDS patient. The Botes model for nursing research guided the methodological assumptions(Botes, 1995:5).

\section{RESEARCH METHODOLOGY}

\section{Research design}


A qualitative research design was used to explore and describe the nurse's experience of the dying process of the terminally ill AIDS patient as this design is effective in exploring and describing a person's experience of a phenomenon (Burns \& Grove, 1997:27). Exploration and description could be defined as an in-depth investigation of an unknown terrain that could accurately and comprehensively be illustrated with words (Mouton \& Marais, 1992:45, 46). This research took place at three provincial hospitals in the $\mathrm{KOSH}$ (Klerksdorp, Orkney, Stilfontein and Hartbeesfontein) and Potchefstroom areas in the North West Province.

\section{Research method}

\section{Sampling}

A focused, voluntary sample was used and inclusion criteria were implemented to select a sample of professional nurses from three provincial hospitals in the selected areas. These inclusion criteria determined that a participant: should be a professional nurse who works in one of the provincial hospitals; should have been nursing terminally ill AIDS patients for at least the past year; may represent any culture, gender or religion; should be able to communicate in Afrikaans or English, and should give written consent to participate in the interviews.

The sample size was governed by data saturation reached after 10 interviews. Participants represented different cultures, including black, white and coloured South Africans.

Prior to the interviews the management at the provincial hospitals provided written consent and chief professional nurses-in-charge identified participants and acted as intermediators. Participants consented in writing and private interviews were conducted on hospital premises.

\section{Data collection}

The process of in-depth interviewing was used to explore and describe the nurse's experience of the dying process of the terminally ill AIDS patient. An introductory question ("How do you experience the dying process of the terminal AIDS patient?') was asked. Communication techniques such as minimal verbal response, paraphrasing, reflection, clarifying and summarising (Okun, 1992:70-71) were used to encour- age elaboration. Trial interviews where conducted first, to evaluate the effectiveness of the introductory question and communication techniques. The researcher conducted observational, personal and theoretical field notes after each interview.

\section{Data analysis}

Interviews were recorded (audio taped) and transcribed for coding. Two independent coders (the researcher and the co-coder) coded the transcriptions according to the combination of the coding techniques of Tesch (in Creswell, 1994:145-155) and Giorgy (in Omery, 1983:57-58). These techniques include: reading transcripts intensively; identifying underlying themes relating to the introductory question; writing these themes down; noting own impressions and thoughts; exploring these themes and identifying categories and sub-categories from the themes. Finally, the identified categories where refined and a consensus discussion clarified the main and sub-categories.

\section{TRUSTWORTHINESS}

To ensure trustworthiness, the framework of Guba and Lincoln (1989:236-243) was combined with the model of Woods and Catanzaro (1988:136) for validity and reliability (See Table 1). The criteria identified were credibility, transferability, dependability and conformability and these were combined with strategies towards trustworthiness.

In this research over-involvement of the researcher; selection of participants and mortality of participants during the research process, were identified as credibility threats. Various control mechanisms were activated. Such mechanisms included: using independent data analysis and a co-coder; a literature control; accurate field notes; purposive, voluntary sampling according to strict inclusion criteria; autonomous decision to participate; single and unstructured interviews as well as limiting time-lapses between consent and interviews.

By providing a comprehensive description of the context of this research, the researcher strived to ensure transferability in this study. Control mechanisms were also activated to decrease the threats to the dependability and confirmability in this study. 
Table 1: Strategies that ensured trustworthiness in this research

\begin{tabular}{|c|c|c|}
\hline Criteria & Threat & Control \\
\hline Credibility & $\begin{array}{l}\text { Selection process of } \\
\text { participants } \\
\text { Mortality of the participants } \\
\text { during the research process }\end{array}$ & $\begin{array}{l}\text { - Independent data analysis by the researcher and co- } \\
\text { coder. } \\
\text { A lierabure control to indicate new information that did not } \\
\text { appear in the literature and information that was both in } \\
\text { the literature and in the research. } \\
\text { Researcher explained her role and posinon in the research } \\
\text { results. } \\
\text { The researcher kept field notes, namely methodological } \\
\text { notes and descriptive and personal notes, to verify } \\
\text { findings. } \\
\text { A purposive, voluntary sample was selected. } \\
\text { Intermediatcrs were used to identify participants. } \\
\text { Strict inclusion criteria were used. } \\
\text { Participants made an sutonomous decision to participate. } \\
\text { A single, unstructured interview was conducted with each } \\
\text { participant. } \\
\text { Limited time elapsed between consent and interviews. } \\
\text { The participants availability to be intervicwed was } \\
\text { emphasised. }\end{array}$ \\
\hline Transferability & \multicolumn{2}{|c|}{ A comprehensive description of the unique context of this research was provided. } \\
\hline Dependabīty & Resercher's fole and functions & $\begin{array}{l}\text { - An independent co-coder was utilised and two consensus } \\
\text { discussions folowed. } \\
\text { - Selection was done according to strict inclusion criteria. } \\
\text { - Participents mede an autonomous decision to participete. }\end{array}$ \\
\hline Confimsbinty & $\begin{array}{l}\text { The raw data, field notes and dat } \\
\text { categories are available for audit }\end{array}$ & $\begin{array}{l}\text { th analysis documents as wel as the inferpretation of the } \\
\text { ing. }\end{array}$ \\
\hline
\end{tabular}

\section{ETHICAL ASPECTS}

To ensure ethical conduct the research utilised aspects from Brink (1996:39-46), Burns and Grove (1997:204207) and DENOSA (1998). Primary ethical considerations included respect for others, beneficence and fairness. These ethical considerations were obliged through informed written consent that secured the participants' right to voluntary participation. Anonymity and confidentiality were ensured throughout the study. The principles of beneficence were also confirmed. Lastly, the participants' right to fair selection and privacy was enforced.

\section{RESULTS AND LITERATURE CONTROL} REGARDING THE PROFESSIONAL
NURSE'S EXPERIENCE OF THE DYING PROCESS OF THE TERMINALLY ILL AIDS PATIENT

Results were organised into six categories. A summary of each category enforced by quotes of participants, relevant literature and emergent themes, is discussed after the results.

\section{Category 1: Experiences regarding the course of the dying process of the termi- nally ill AIDS patient}

Nurses experience that various aspects affect the pace of the dying process. One such aspect is that the pace of dying accelerates as soon as patients are informed 


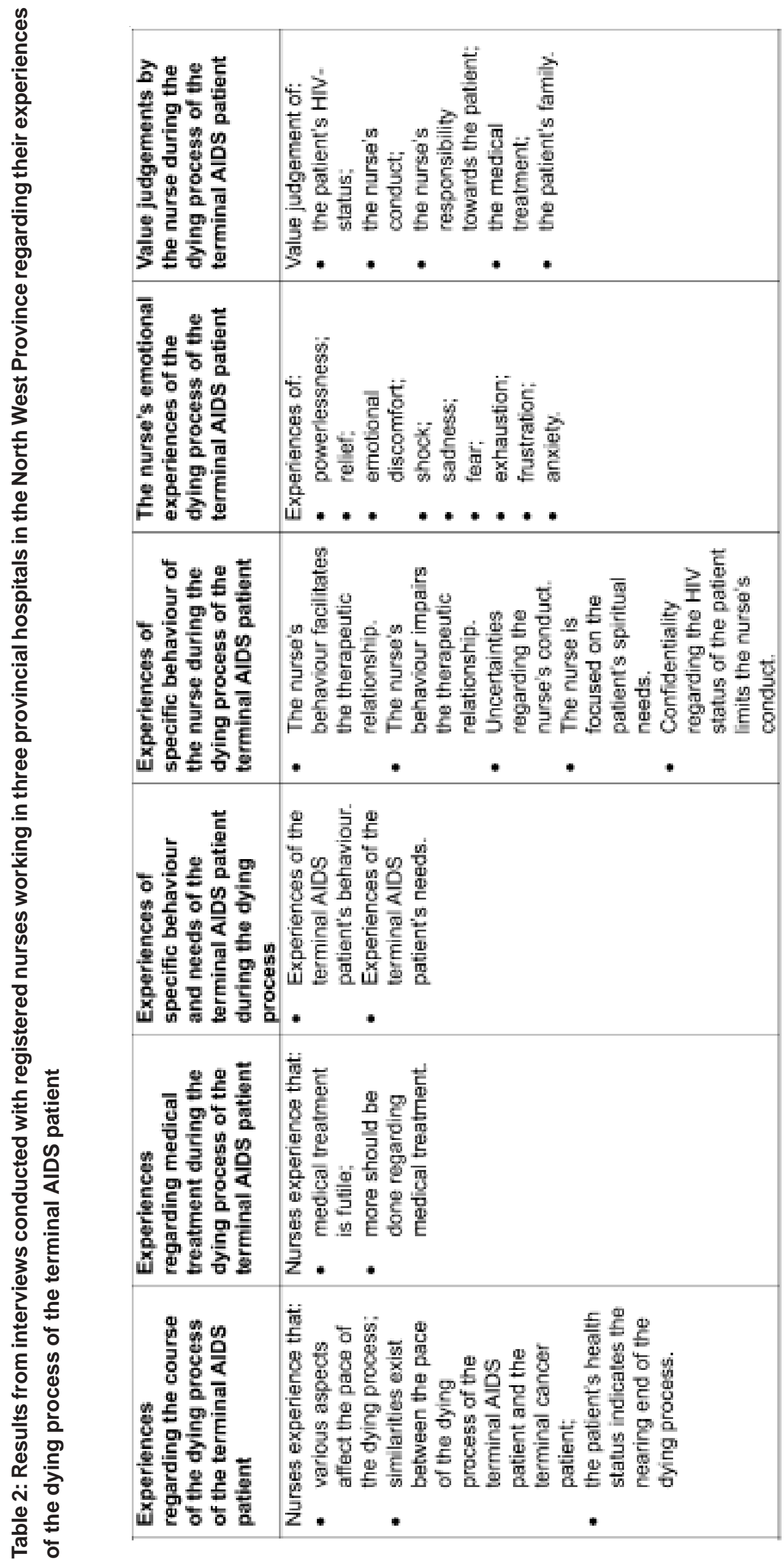


of their HIV positive status or AIDS diagnosis. A professional nurse stated: "Most of them, as soon as the doctor tells them that they are positive, they deteriorate". "Very fast".

Nurses also experience that the dying process is accelerated when patients are re-admitted in a debilitated state after being discharged to be cared for at home. A nurse employed at a male unit responded: "And often, two days after they went home, they come back, deadly ill'.

A nurse stated: "Good nutrition, and so on, because they can live for a long time". This implies that they are of the opinion that a healthy lifestyle postpones death, as it enhances the patient's immunity against infections. Nurses view a healthy diet and immunity enhancing agents as important aspects of a healthy lifestyle.

Another aspect is the socio-economic status of the patient. Nurses experience that the pace of the dying process of patients with a lower socio-economic status is more rapid than those with a higher socio-economic status. They mention that the latter group has more access to resources that contribute to a healthy lifestyle. The following quotes illustrate this finding: “... and they have the right circumstances socially ... and everything then they survive it a bit longer"; "... and they don't have money to pay. They're from low social economy groups".

Various authors confirm that the aspects mentioned by nurses might have an influence on the pace of the dying process of the terminally ill AIDS patient (Tancred, Van Rensburg \& Joubert, 2000:30; Uys, 2000:162; Clark, 1996:238-240, 594-595).

The results further indicated that nurses observe similarities between the dying process of the terminal AIDS patient and the terminal cancer patient, specifically the duration of the dying process. As quoted: “... the dying processes of patients with AIDS and cancer ... For me it's basically the same because they also just lie there. Some take so long, they also don't get better".

Furthermore, nurses believe that AIDS patients, as those with cancer, experience death as a relief from the suffering they experienced during the dying process. The following statement supports this finding: "... the dying processes of patients with AIDS and cancer is basically the same for me. That suffering and then that relief'.

Sims and Moss (1991:viii) confirm that associations between the dying process of the AIDS patient and that of the cancer patient are often made. However, in literature no references could be found to the similarity between death as a relief for AIDS patients and for cancer patients.

Nurses acknowledge that specific signs and symptoms are characteristic of the patient's debilitated state and serve as an indication of the approaching end. When a patient presents with signs and symptoms such as acute anaemia, internal bleeding, acute vomiting and diarrhoea, status epilepsy or stupor, the nurse anticipates that the death of the patient is approaching within hours or days. Several authors confirm that specific signs and symptoms could be an indication of the final phase of the dying process (Alexander in Anderson, 2000:361; Cabell, 2000:1-3; Sims \& Moss, 1991:42).

\section{Category 2: Medical treatment during the dying process of the terminally ill AIDS patient}

Contrasting results emerged regarding the medical treatment of terminally ill AIDS patients. On the one hand, the nurse experiences that medical treatment is futile and prolongs the dying process. On the other hand, the nurse expresses the notion that medical treatment should receive attention as it increases hope that the patient's suffering will be reduced. A nurse in a female ward remarked: "They can say that it will prolong their lives a little bit. But at the end they still die". Another nurse stated: "Then you give them pain medication like Panado or Dolorol to help reduce the pain they experience".

Nurses also experience that doctors base treatment decisions only on the patient's HIV and AIDS diagnosis, prognosis and the availability of medication. They experience this as unfair, and this causes conflict between the nurse and the doctor: "Mmm ... and again sometimes the doctor will come and tell you for this patient there should be no, no active resuscitation. But the minute the child is gasping there and you are trying to do something for the child, the mother is expecting 
you to call the doctor. So, some of the doctors make it more difficult for you, because when you phone the doctor and tell the doctor the condition, they are telling you there is nothing I can do, I am not coming there... the child is going to die. But you lie sometimes ... just to comfort her".

This quote also relates to a further finding, namely that the nurse experiences that the termination of medical treatment causes trauma for the patient's family. Alexander (in Anderson, 2000:345) confirmed that the transformation from curative to palliative treatment of AIDS patients is considered very difficult for the patient, the family and the nurse.

\section{Category 3: Experiences of specific behaviour and needs of the terminal AIDS patient during the dying process}

Nurses experience that terminal AIDS patients demonstrated specific behaviour and have specific needs. With reference to their behaviour, nurses experienced that patients seem to be calmed by physical contact: "Then they go on the ventilators, then they become anxious, then you have that contact that you give him. He then naturally becomes more calm". Alexander (in Anderson, 2000:369) acknowledges the therapeutic value of physical contact for the terminally ill AIDS patient.

Additionally, nurses experience that patients do not accept the reality of the illness and are not interested in learning more about HIV and AIDS. The following quotes illustrate this result: "They know this disease, but they feel it's not there ... don't want to accept the reality"; "They also won't tell you about it and it doesn't help to tell a patient if he is not interested. Because they don't listen to you'. Deetlefs (1998:57) found that nurses act in the belief that AIDS patients deny that AIDS exists.

The results also show that nurses experience that terminally ill AIDS patients often request to be discharged to be with their family and to die at home: "Yes, in those moments that they realise it could be their last days, many of them prefer to go home; many ask 'Sister, can you ask Doctor to send me home, so that I could be at home, among my people, my family, my next of kin, so that they can be with me in those last moments". "Many really request this".

Additionally, nurses experience that both the patient and his family need support. However, they admit that they do not always succeed in providing that support. A nurse in a neonatal ICU responded: "You don't really think of the needs of the family and the needs of the patient for support'. Literature indicates that patients generally have a need to die at home and that family support is central to the dying process (Penson \& Fisher, 1995:179).

During the last phase of the dying process, nurses experience that patients are dependent on them for help with all their basic needs: "Then they can't drink anymore. They can't help themselves, when they are at that final point isn't it'. This finding was confirmed by both Deetlefs (1998:68) and Cabell (2000:1-3).

\section{Category 4: Experiences of specific behaviour of the nurse during the dying process of the terminally ill AIDS patient}

In this category, the research results firstly found that nurses experience that their conduct could both facilitate and obstruct the therapeutic relationship with the patient and his family. Facilitative behaviour occurs when nurses identify with the patient, do more than just basic nursing and get to know patients during their prolonged stay in hospital. Nurses experience that they then become more empathic, understanding and supportive. The following quotes illustrate these findings: "... especially if you place yourself in that situation, it could've been my brother ..."; "... and I have to say we go the whole way and we give everything that we can"; "They become part of the ward. And, so, you get accustomed to them. So, they touch everyone's heart'.

Literature generally confirms that nurses tend to identify with patients (Samarel, 1991:69), provide comprehensive care to AIDS patients (Sims \& Moss, 1991:94) and perceived that physical care of AIDS patients intensifies the relationship between the patient and the nurse.

Secondly, nurses also experience difficulties in their therapeutic relationship with terminally ill AIDS patients and their families. Although nurses are aware of their needs, their increased workload limits the time they 
can spend with them: "Because wards are congested with patients ... you do not get around to doing it (attending to terminal AIDS patients' needs) in a general hospital setting".

Thirdly, nurses also experience that difficulties are caused by limited medical treatment, as well as their own incompetence in discussing the patients' diagnosis, prognosis, precautionary measures and treatment, with them. As quoted: "The most traumatic part of it is to explain ... and it becomes more difficult when the mother will ask you 'It means I am going to die too?' You know, it is a difficult question to answer. Because you cannot see when you are going to die, how are you going to die".

The fourth result in this category was that nurses harbour ethical questions regarding the medical treatment of terminally ill AIDS patient. If these questions influence their spontaneity towards and acceptance of the patient, it could impair their relationship: "So I feel it's difficult. It's an ethical decision. It's bad'. Several authors confirm these findings (Samarel, 1991:94; Vlok, 1996:616; Rancour, 2000:24).

Furthermore, nurses experience uncertainty about their conduct towards the patients and their families during the dying process. Their uncertainty arises from their experience that the family questions the patient's treatment as stated: "You meet some of the patient's next of kin and ... they ask so many questions. One can't always ... know what to say". Zisook (in Kaplan \& Sadock, 1995:1713) confirms that questions about HIV and AIDS are difficult to answer because of ethical issues.

Another founding was that nurses experience that they actively focus on the spiritual needs of terminal AIDS patients: "Read a verse or something and sometimes you won't read a verse that has reference to his condition, but that which you feel will be good for him". They also refer patients to a spiritual leader when they feel incompetent to provide the necessary spiritual care themselves: "We have called the congregation or pastor for them several times, to give a sermon". Sims and Moss (1991:94) acknowledge the therapeutic value of spiritual support by caregivers, in this case nurses, to terminal AIDS patients.
Nurses also express negative views on the confidentiality of the patients' HIV and AIDS status. They claim that confidentiality prevents them from providing the patients and their families with adequate education and support. Deetlefs's research (1998:54) confirmed that nurses experience the care of AIDS patients as inadequate, and various authors (Piot in UNAIDS, 2000:89; Thom, 2000:1) acknowledge that the increased hospitalisation of terminal AIDS patients creates time pressure that prevents optimal care.

\section{Category 5: The nurse's emotional expe- riences of the dying process of the termi- nally ill AIDS patient}

Results revealed a complex range of emotional experiences that will be discussed briefly below.

Firstly, powerlessness is expressed because nursing cannot cure the terminal AIDS patient: "And your objective at that stage is to do everything we can do. It is as if it just doesn't help. So, it's very difficult'. Nurses could not explain the dying process to terminally ill children, which also promotes feelings of powerlessness, as stated: "Everything is so difficult and you cannot explain to a child what is happening to him".

In contrast with the emotion of powerlessness, nurses also experience relief when the patient dies, as this ends his suffering: "So, it's difficult to say ... it is an absolute deliverance".

Emotional discomfort is another identified theme. Nurses experience emotional discomfort when discussing diagnosis, prognosis and treatment with the patients and their families. Fourthly, nurses experience shock about the patient's family's seemingly indifferent behaviour towards young terminal children and newly diagnosed patients; about realising that people whom the nurse personally knows are diagnosed as HIV positive, and about the young age of terminal AIDS patients. A nurse expressed her experience of shock by through these words: "Now I know she, the patient, is positive, but we shouldn't know. This is actually a shock to me, because she was so young and decent. And I knew she is living the right life".

The fifth emotional experience expressed, was grieving for the terminally ill AIDS patients and their families. 
This intensifies when dealing with babies and their mothers. The following quote supports this finding: "The patient that dies of AIDS, it's very sad to see".

The risk of HIV infection causes fear and exhaustion due to the high number of deaths and the lack of time to process their feelings, as quoted: "You don't want to work with the patient. You are scared that you will also get the disease"; "You are physically exhausted, but it is as if you see that face in front of you every now and then".

The community's apathy and limited medical treatment cause the nurse to experience frustration. As a nurse said: "Our people, it's difficult for them to accept this disease, because when you tell them to be careful, they will tell you it's because you don't want them to enjoy life". The final theme in this category is the nurse's concern that her own family may become infected by the HI-virus: "Because I feel people are dying and I am worried, because I have young girls".

From literature it was found that Kübler-Ross (in Richards \& Johnson, 1982:66) confirmed that nurses experience complex emotional discomfort when managing and discussing death and the dying process.

\section{Category 6: Value judgement by the nurse during the dying process of the terminally ill AIDS patient}

A result listed in the sixth category is that nurses make value judgements of terminal AIDS patients because of their HIV status. They believe that women and children are victims of men's irresponsible behaviour: "Those guys left their wives at home and then when they came to them (women who practice prostitution to earn money to care for their children), they came with money. They don't wear condoms".

Secondly, they also believe that young people, who became HIV positive in spite of health education, should carry the blame for their HIV positive status: "The young patients, look, a lot of education is being given in this country. So I think the younger people are not so innocent". But despite this, nurses are of the opinion that patients should be nursed with respect and dignity: "Every person has his own dignity".
Additionally, nurses expressed that they pretend that they are unaware of the patient's HIV status, as stated: "I try to pretend as if there is nothing". She then nurses the patient to the best of her ability: "So we try to nurse them as best we can".

Another result was that Christian nurses believe that they should display empathy towards patients and should educate them: "Especially when you are a Christian you feel sometimes as you empathise, you sympathise with this person, you feel the pain the person is experiencing, you feel the pain the family is experiencing"; "So, as a Christian, measures should be devised so that this people should be taught modesty".

Value judgements towards the medical treatment of terminal AIDS patients also manifested. Nurses believe that expensive medical treatment, specifically medication and blood transfusions, should be withheld from dying AIDS patients, as they have a poor prognosis: "They can't give too expensive treatment, because the patients are already terminal. You know that it is not really going to help".

The seventh result was that nurses believe that hospitalisation of terminal AIDS patients causes high bed occupancy, at the expense of HIV negative patients with better prognoses: "Because there are other patients who are more entitled to this treatment, who are negative". Yet, the results indicated that nurses believe that terminal AIDS patients have the right to medical treatment, as quoted: "And every time they come, they must get different kinds of antibiotics, because they get these opportunistic infections. They must be treated".

The final value judgement is aimed at the terminal AIDS patient's family. Nurses believe that HIV-positive mothers should not have more children: "I don't know if it will help if you tell an HIV positive baby's mother, who is also HIV positive, to use contraception to prevent pregnancy. I don't know if she will listen, because all these babies die in the end'. Nurses also observed that families have negative attitudes towards the terminal AIDS patient, which is apparent through their limited display of emotions and avoidance. The following quote demonstrates this finding: " $A$ lot of families don't want to get involved, and don't want to look after the patient". 
Although various authors (Piot in UNAIDS, 2000:8; Thom, 2000:1; Witt Sherman, 2000:1505) discussed the increased, problematic and unnecessary bed occupancy by terminal AIDS patients, the literature does not suggest that treatment should be withheld from these patients.

\section{CONCLUSION}

Nurses indicate that the terminal AIDS patient's dying process is affected by factors such as knowledge, readmissions, lifestyle and economic status. They compare the dying process of terminal AIDS patients with that of the terminal cancer patients, which is more familiar to them. Contrasting opinions are expressed regarding the medical treatment of terminal AIDS patients. On the one hand they experience medical treatment as futile, but on the other hand they feel that medical treatment could reduce suffering. Nurses also experience that the terminal AIDS patient has specific behaviour and needs during the dying process. They realise that their behaviour could facilitate or impair the therapeutic relationship. Confidentiality is experienced as negative. A complex range of emotional experiences also surfaced. Finally, nurses display value judgements towards the terminal AIDS patients, their families, medical treatment and their own conduct during the dying process.

\section{RECOMMENDATIONS}

Recommendations relevant to nursing education are grouped into curriculum content and in-service training. It is recommended that curriculum content should include the following guidelines when nursing the terminal AIDS patient: enhancing the student and registered nurse's communication skills in conversations on life and death; facilitating nurses' provision of terminal guidance to terminal AIDS patients in the scientific nursing process and planning in-service training programmes to continually support nurses exposed to the dying process of the terminal AIDS patient.

Support should provide an opportunity for ventilation of feelings, referral and temporary transfer to other wards. It should also be an opportunity for nurses to identify and deal with bereavement in their own lives. Such support could heighten coping skills developed during their exposure to the dying process of the terminal AIDS patient. Frequent follow-ups are also suggested to ensure continued support.

Further research into the nurse's skills in this situation is required. It is suggested that continued research could focus on: managing conversations on life and death with the terminal AIDS patient; exploring the impact of using the patient's native language when dealing with emotive themes; considering culture-congruent nursing of the terminal AIDS patient within a culturally diverse milieu; investigating the nurse's experience of meaning and purpose while nursing terminal AIDS patients who are dying and finally understanding the nurse's role within the multidisciplinary team during this process.

Recommendations for nursing practice could serve as guidelines towards facilitating effective management of exposure to the dying process of the terminal AIDS patient. These are discussed in the three categories of personal coping, extended coping skills and handling of specific themes during this dying process.

\section{Category 1: The nurse's personal coping with the dying process}

To cope with the dying process of the terminal AIDS patient, nurses should get clarity on their meaning of life and death. To achieve this psychological and extended coping skills regarding the dying process are necessary. Facilitation could explore nurses' clarification of life and death (Thomas \& Retsas, 1999:200) according to their paradigmatic perspectives. The nurses could then identify the specific meanings that they attach to death (Kleinke, 1991:177) that should be congruent with their religions and their value systems. Such a process may add meaning and purpose to their exposure to the dying process of terminal AIDS patients. The nurse should also be supported to explore her own mortality (Kübler-Ross, 1981:20-22), a process that might be disruptive and painful. During this exploration the nurse could be challenged to develop an eternity perspective (Rinpoche, 2001:1). The nurse should then be motivated to utilise spiritual power (Witt Sherman, 2000:1506) that could imply supportive prayer or meditation when nursing the terminal AIDS patient.

Facilitation to find a balance between the personal and 
professional self (Witt Sherman, 2000:1506) to clarify identity and a value system, could promote psychological coping. According to Wilson and Kniesl (1992:26) venting could increase emotional self-awareness and identify dormant emotions. Nurses should also be encouraged to redefine the hope (Benzein \& Saveman, 1998:328) that they have in the nursing of terminal AIDS patients. This should be defined as a more positive and active hope. Finally, they should be guided to identify areas for personal growth (Kleinke, $1991: 132)$ during the exposure to the dying process.

\section{Category 2: Extended coping skills in the terminal guidance of terminal AIDS pa- tients}

A complete or refresher course on terminal guidance could be useful. Furthermore, facilitation could assist the nurse to acknowledge the difficulty and inevitability of conversations on life and death (Rancour, 2000:24). This could be followed by role-play conversations to refine communication and interpersonal skills (Wilson \& Kniesl, 1992:149-152). The nurse should be reminded to provide for the patient's uniqueness during terminal guidance and to avoid a clinical approach. The SPIKES acronym used by Buckman (in Rancour, 2000:24) could be used as a basis for conversations on life and death. This could be summarised as follows: ensure a therapeutic situation through privacy, eye level contact and general comfort; explore the patient's perceptions of HIVIAIDS and identify any misperceptions, for further use during the conversation; invite patients to vent their emotions while evaluating their knowledge of HIVIAIDS; explore alternatives with the patients to manage and cope with their terminal health status and summarise the conversation and the patients' chosen strategies.

\section{Category 3: Management of specific themes during the dying process}

Nurses should acknowledge that although families are not actively involved in the patients' nursing, they contribute to their quality of life during the dying process (Kleinke, 1991:179). Additionally, they should acknowledge that the family might exhibit culturally diverse behaviour (Kleinke, 1991:129-131) during the dying process. They should identify this to increase their knowledge of such behaviour. Deprived grief (Kleinke, 1991:134) may surface within the family and this too should be discussed with nurses.

The nurse should be allowed to vent emotions during the dying process of young terminal AIDS patients (Payne, Dean \& Kalus, 1998:705). A simulated discussion could explore themes such as the length of life versus quality of life (Graham, 1988:75).

Facilitation could clarify the nurse's values and beliefs regarding the medical treatment of the terminal AIDS patient. This should take place prior to the discussions of treatment with the multidisciplinary team. A monthly unit meeting could discuss new treatment developments. Such meetings could explore recent policies and other aspects of treatment. This information should be kept in a separate file, in compliance with legal requirements. Cost-effective nursing of the highest standard should be promoted. This could include alternative interventions such as massaging, therapeutic touching and religious therapy. A monthly multidisciplinary team meeting could be initiated. This meeting could focus on in-service training, appropriate referrals and optimal healthcare of the terminal HIV/ AIDS patient.

Another recommendation is that the nurse could also list personal ethical questions regarding the nursing of the terminal AIDS patient. Discussion that incorporates the following resources should then be facilitated: the nurse's life view and religious framework; codes of ethics for the nursing profession; rules and regulations; relevant legislation; professional standards and human rights principles.

Finally, recent statistics and scientific sources could be used to place the HIV infection risk in realistic perspective. Van Dyk (1992:25-27) stresses that applying universal precautionary measures is sufficient to prevent the HIV infection of nurses.

\section{SUMMARY}

The aim of this research was to explore and describe the nurse's experience of the dying process of the terminally ill AIDS patient, to formulate guidelines that could facilitate the nurse to deal with exposure to the dying process more effectively. In the researcher's opinion this was achieved. Prior to this study, relevant literature was studied. This indicated an increase in the hospitalisation and death of terminal AIDS patients in 
South Africa. Nurses are primary caregivers during the hospitalisation of terminal AIDS patients. HIVIAIDS, is associated with a unique dying process that may intensify nurses' experiences and affect them personally.

The results confirm a complex experience. Nurses indicate that various aspects affect the pace of the dying process and contrasting experiences surfaced regarding medical treatment. They identify aspects in their own behaviour that could facilitate or hamper the therapeutic relationship. Nurses' varied emotional experiences illustrate the impact of the dying process. They make value judgements of the patients, their families, medical treatment and their own conduct during the dying process.

Guidelines were formulated for nursing education, research and the practice. Guidelines for the nursing practice were structured in the form of recommendations. These recommendations relate to the nurse's personal coping with the dying process, extended coping skills in terminal guidance and handling of specific themes during the dying process of the HIVIAIDS patient.

\section{BIBLIOGRAPHY}

ANDERSON, J ed 2000: A guide to clinical care of woman with HIV. Rockville: Department of Health \& Human Services, Health Resources \& Services Administration, HIVIAIDS Bureau. ANON 2005: Wêreldstatistiek UNAIDS/WHO. Slide 4. http:// ww.jeugfokus.org.za. (Accessed: 4 January 2005).

ANON 1998a: VIGS tref dié deel van Afrika erg. Rapport, 18, 6 October 1998.

ANON 1998b: March of a human catastrophe. Mercury, 1, 9-10 November 1998.

BENZEIN, E \& SAVEMAN, BI 1998: One step towards the understanding of hope: A concept analysis. International Journal of Nursing Studies, 35(6):322-329.

BESTER, ME \& ARENDSE, Y 1996: Kennis en houding van verpleegstudente aangaande VIGS in 3 opleidingsinstansies in die Wes-Kaap. Curationis, 19(4):64-66.

BOTES, AC 1994: ' $n$ Model vir etiese besluitneming in verpleging. Curationis, 17(4):66-70.

BOTHA, ME 1995: 'n Wêreld wat aan God behoort. Inleiding tot 'n Christelike werklikheidsleer (Ontologie). Potchefstroom: PU vir CHO. (Studiegids D3/92).

BRINK, H 1996: Fundamentals of research methodology for health care professionals. Kenwyn: Juta.
BURNS, N \& GROVE, SK 1997: The practice of nursing research: conduct, critique and utilization; $3^{\text {rd }}$ edition. Philadelphia: Saunders. CABELL, K 2000: Death: What you can expect. http://emanon.net/ $\sim$ k.cabell/signs.htm (Accessed: July 2000).

CHAMANE, N.J. \& KORTENBOUT, W 1997: Professional nurse's knowledge and understanding of HIVIAIDS infection. Curationis, 20(2):43-46.

CHIPFAKACHA, AG, chair 1998: World Health Organization UNAIDS. AIDS epidemic update: December. Mmabatho: Department of Health and Social Development.

CLARK, MJ 1996: Nursing in the community; $2^{\text {nd }}$ edition. Stanford: Appleton \& Lange.

CRESWELL, JW 1994: Research design: Qualitative and quantitative approaches. Thousand Oaks: Sage.

DEETLEFS, E 1998: Die houding van verpleegkundiges teenoor die MIV-positiewe pasiënt. Potchefstroom: PU vir CHO. (Unpublished Master Thesis)

DENOSA (Democratic Nursing Organisation of South Africa) 1998:

Position statements. 2.2.1-2.2.4. Pretoria: Denosa

DEPARTMENT OF HEALTH 2003: National HIV and Syphilis Antenatal Sero-prevalence Survey in South Africa: 2002. Summary Report. Pretoria: Government Printers.

GRAHAM, B 1988: Die dood en die lewe daarna. Kaapstad: Struik. GUBA, EG \& LINCOLN, YS 1989: Fourth generation education. London: Sage.

KAPLAN, HI \& SADOCK, BJ 1995: Comprehensive textbook of psychiatry. Volume $1 \& 2 ; 6^{\text {th }}$ edition. Baltimore: Williams \& Wilkens. KLEINKE, CL 1991: Coping with life challenges. Pacific Grove: Brooks/Cole.

KÜBLER-ROSS, E 1981: Living with death and dying. London: Souvenir.

MOUTON, J \& MARAIS, HC 1992: Basiese begrippe: Metodologie van die geesteswetenskappe. Pretoria: RGN.

O'GORMAN, SM 1998: Death and dying in contemporary society: An evaluation of current attitudes and rituals associated with death and dying and there relevance to recent understanding of health. Journal of Advanced Nursing, 27(6):1127-1135.

OKUN, BF 1992: Effective helping interviewing and counselling techniques; $4^{\text {th }}$ edition. California: Brooks/Cole.

OMERY, A 1983: Phenomenology: A method for nursing research. Advances in Nursing Science, 5(2):49-63.

ORAL ROBERTS UNIVERSITY ANNA VAUGHN SCHOOL FOR NURSING 1989: A syllabus and general guide for theories in nursing. Fall semester 1989. Tulsa: Oral Roberts University.

PAYNE, SA; DEAN, SJ \& KALUS, C 1998: A comparative study of death anxiety in hospice and emergency nurses. Journal of Advanced Nursing, 28(4):700-706.

PENSON, J \& FISHER, R 1995: Palliative care for people with cancer; $2^{\text {nd }}$ edition. London: Arnold. 
RANCOUR, P 2000: Those tough conversations. American Journal of Nursing, $100(4): 24 \mathrm{HH}$.

RICHARDS, L \& JOHNSON, P 1982: Death and the caring community: Ministering to the terminally ill. Portland: Multonamah.

RINPOCHE, S 2001: Finding meaning in life. http://www.spcare.org/ fdfh/excerptx/findingmeaning/html. (Accessed: 17 April 2001).

ROBBINS, J \& MOSCROP, J 1995: Caring for the dying patient in the family; $3^{\text {rd }}$ edition. London: Chapman \& Hall.

SAAB, BR \& SEOUD, M 1998: Lessons from a courageous dying patient. World Health Forum, 19(3):324-327.

SAMAREL, N 1991: Caring for life and death. New York: Hemisphere Publishing Corporation.

SIMS, R \& MOSS, VA 1991: Terminal care for people with AIDS. London: Edward Arnold.

ST LEGER, C 1995: AIDS crisis deepens in South Africa. Sunday Times, 27 August 2005:5.

SWANEPOEL, T 1998: Verander nou die houding. 'Grondslag vir openlikheid oor VIGS is nodig'. Beeld, 12 Augustus 1998:11.

TANCRED, HAJ; VAN RENSBURG, PHJJ \& JOUBERT, G 2000: The prevalence and severity of major depression in heterosexual male HIV infected patients in the OFS. The Medical Journal, 42(5):2731.

THOM, A 2000: Gauteng trying to come to grips with an epidemic threatening to overwhelm the hospitals. www.suntimes/2000/ ST000202.htm. (Accessed: 5 Febuary 2000).

THOMAS, J \& RETSAS, A 1999: Transacting self-preservation: A grounded theory of the spiritual dimensions of people with terminal cancer. International Journal of Nursing Studies, 36(3):191-201.

TORRENTE, AC \& GREEFF, M 1996: Riglyne vir die fasilitering van heelheid by die pasiënt met VIGS: Die belewenis van die pasiënt met VIGS: Deel 1. Curationis, 19(1):11-18.

UNAIDS 2000: Ethical considerations in HIV preventive vaccine research. (In: UNAIDS Guidance document 2000.) [CD ROM.]

UYS, LR 2000: Confidentiality and HIVIAIDS in South Africa. Nursing Ethics, 7(2):158-166.

VAN DYK, AC 1992: AIDS: The healthcare challenge: A practical guide for nurses, doctors and healthcare professions. Pretoria: Alteks.

VLOK, ME 1996: Manual of community nursing: Communicable diseases; $5^{\text {th }}$ edition. Kenwyn: Juta.

WHO (World Health Organization) 2000: WHO report for G8 meeting. http://clinic.co.za.jul001/poverty24.htm (Accessed: 19 March, 2001).

WILSON, HS \& KNIESL, CR 1992: Psychiatric nursing; $4^{\text {th }}$ edition. Redwood City: Addison-Wesley.

WITT SHERMAN, D 2000: Experiences of AIDS-dedicated nurses in alleviating the stress of AIDS care giving. Journal of Advanced Nursing, 31(6):1501-1508.
WOODS, NF \& CATANZARO, M 1988: Nursing research: Theory and Practice. St Louis: CV Mosby. 